\title{
Human saliva as an effective sample for the detection of COVID-19
}

\section{Kaveh Nasiri* \\ Independent researcher, Essen, Germany}

\section{Letter to editor}

In the oral cavity of the human body, there are three major salivary glands; parotid, submandibular, and sublingual as well as 300 to 400 minor salivary glands, all of which secret saliva. Saliva consists of proteins, hormones, antibodies and other molecular compounds that are typically measured in a routine blood test. Therefore, saliva is considered as a diagnostic window for the detection of various diseases, such as oral cancer, periodontal diseases, and COVID-19 [1,2]. This brief letter focused on the detection of COVID-19 using saliva samples as a form of liquid biopsy via point-of-care technology.

The coronavirus disease 2019 (COVID-19) is caused by severe acute respiratory syndrome coronavirus (SARS-CoV-2), and first appeared in Wuhan city, China, in December 2019. Coronavirus contains four main proteins, namely spike (S), membrane (M), envelope (E), and nucleocapsid $(\mathrm{N})$, which are essential for genome maintenance and virus replication. Particularly the spike protein facilitates the route transmission of COVID-19 by latching onto cellular attachment factor, i.e. angiotensin-converting enzyme 2 (ACE-2) in host cell. Since ACE2 cells cover the salivary gland ducts, they are the first target of SARS$\mathrm{CoV}[3,4]$.

There are several methods of collecting specimen for the detection of COVID-19, including nasopharyngeal swab and oropharyngeal swab. However, they are reported to be uncomfortable, painful, and invasive. Also, there is the risk of transmission of the virus to healthcare providers. On the contrary, saliva sampling method is non-invasive, safe and effective particularly for monitoring COVID-19. Examples of saliva collection devices are Salivette (Sarstedt), Quantisal (Immunalysis), and SCS (Greiner-BioOne) [1,2].

The study conducted by Azzi et al. [5] shows that sampling saliva is a reliable method in COVID-19 diagnosis compared to nasopharyngeal swab. In this study, saliva samples of 25 COVID-19 patients were examined by Real Time reverse transcription Polymerase Chain Reaction (rRT-PCR). The samples were collected through two methods; saliva sampling and pharyngeal or bronchoalveolar swab. A noticeable result was obtained; in two patients saliva samples showed positive, whereas their respiratory swab, which was performed on the same day, proved otherwise [5]. Thus, sampling saliva can be confidently used in the detection of coronavirus. Moreover, it can help researchers to obtain some information about the clinical evolution of COVID-19.

Given the features of saliva, a biological fluid, it can be used for rapid tests, such as point-of-care (POC) tests. Point-of-care (POC) technology is defined as simple medical tests that can be performed in low-resource environments outside of a laboratory, including at home.
Considering the status quo, point-of-care tests can be of great value and importance in the diagnosis of COVID-19 in suspected patients. Thus, diagnosing COVID-19 via POC with saliva as specimen can play a crucial role in this circumstance. For instance, STOP (SHERLOCK (Specific High Sensitivity Enzymatic Reporter UnLOCKing) Testing in One Pot) is a STOPCovid method for the detection of COVID-19. This method is applied as follows: 1. using saliva sample and adding it to lysis buffer. 2. transferring the sample to SHERLOCK and putting the sample tube into heat block for 60 minutes at $60^{\circ} \mathrm{C}$. 3. using detection strip and dipping it into SHERLOCK for two minutes. 4. checking the detection strip for result [6].

In conclusion, using point-of-care tests in which human saliva is examined greatly contributes to the rapid detection of COVID-19; thus, they can be widely used in this pandemic situation. POC technology requires minimal equipment and can be used in the comfort of people's own home, at the airport, and in various clinics to identify suspect patients and control the spread of COVID-19 [2]. This letter will help clinicians understand the importance of saliva for diagnostic tests. However, further clinical and laboratory studies are recommended to examine COVID-19 diagnosis via POC method with saliva specimen.

\section{Sources of support}

Self-financed.

\section{Financial support and sponsorship}

Nil.

\section{References}

1. Khurshid Z, Zohaib S, Najeeb S, Zafar MS, Slowey PD, et al. (2016) Human Saliva Collection Devices for Proteomics: An Update. Int J Mol Sci 17(6): 846. [Crossref]

2. Khurshid Z, Asiri FYI, Al Wadaani H (2020) Human Saliva: Non-Invasive Fluid for Detecting Novel Coronavirus (2019-nCoV). Int J Environ Res Public Health 17(7): 2225. [Crossref]

3. Mousavizadeh L, Ghasemi S (2020) Genotype and phenotype of COVID-19: Their roles in pathogenesis. J Microbiol Immunol Infect. [Crossref]

4. Liu L, Wei Q, Alvarez X, Wang H, Du Y, et al. (2011) Epithelial cells lining salivary gland ducts are early target cells of severe acute respiratory syndrome coronavirus infection in the upper respiratory tracts of rhesus macaques. J Virol 85(8): 4025-4030. [Crossref]

${ }^{\star}$ Correspondence to: Kaveh Nasiri, DDS, MSc (Endodontics), Essen 45138, Germany, E-mail: DDS.Nasiri@web.de

Key words: COVID-19, POC testing, Saliva

Received: July 05, 2020; Accepted: July 27, 2020; Published: July 30, 2020 
Nasiri K (2020) Human saliva as an effective sample for the detection of COVID-19

5. Azzi L, Carcano G, Gianfagna F, Grossi P, Gasperina DD, et al. (2020) Saliva is a reliable tool to detect SARS-CoV-2. J Infect 81(1): e45-e50. [Crossref]
6. Joung J, Ladha A, Saito M, Segel M, Bruneau R, et al. (2020) Point-of-care testing for COVID-19 using SHERLOCK diagnostics. MedRxiv. [Crossref]

Copyright: $(02020$ Nasiri K. This is an open-access article distributed under the terms of the Creative Commons Attribution License, which permits unrestricted use, distribution, and reproduction in any medium, provided the original author and source are credited. 